\title{
LEMBAR KERJA SISWA PADA MATERI HIMPUNAN BERBASIS PENDEKATAN PENDIDIKAN MATEMATIKA REALISTIK UNTUK SISWA SMP/MTs
}

\author{
Nurul Arfinanti
}

\begin{abstract}
ABSTRAK
Penelitian ini merupakan penelitian pengembangan. Penelitian ini bertujuan untuk mengembangkan lembar kerja siswa (LKS) berbasis Pendekatan Pendidikan Matematika Realistik pada materi himpunan untuk siswa SMP/MTs.

Model pengembangan yang digunakan adalah model pengembangan prosedural, yaitu model yang bersifat deskriptif, menggariskan langkah-langkah yang harus diikuti untuk menghasilkan produk. Prosedur pengembangan yang digunakan dalam penelitian ini adalah prosedur pengembangan Borg dan Gall yang disederhanakan dengan lima langkah yaitu melakukan analisis produk yang dikembangkan, mengembangkan produk awal, validasi ahli dan revisi, uji coba lapangan skala kecil dan revisi produk, serta uji coba lapangan skala besar dan produk akhir.

Hasil penelitian adalah Lembar Kerja Siswa berbasis pendekatan PMR dengan kualitas keseluruhan sangat baik dengan nilai 70 (90, 35\%). LKS juga sangat efektif digunakan untuk pembelajaran matematika SMP/ MTs. Hal ini berdasarkan ketuntasan siswa secara klasikal dengan persentase $82,86 \%$. Selain itu, respon siswa juga positif terhadap pembelajaran dengan menggunakan LKS pendekatan PMR.
\end{abstract}

Kata kunci: Lembar Kerja Siswa, Pendekatan Pendidikan Matematika Realistik, Himpunan 


\section{PENDAHULUAN}

Matematika merupakan ilmu universal yang mendasari perkembangan teknologi modern, mempunyai peran penting dalam berbagai disiplin ilmu pengetahuan, dan memajukan daya pikir manusia. Mata pelajaran matematika perlu diberikan kepada siswa di jenjang pendidikan dasar dan pendidikan menengah untuk mempersiapkan siswa agar sanggup menghadapi perubahan keadaan di dalam kehidupan dan di dunia yang selalu berkembang melalui latihan bertindak atas dasar pemikiran secara logis, rasional, kritis, cermat, jujur, efisien, dan efektif (Puskur, 2002). Meskipun demikian, masih banyak siswa yang menganggap matematika sebagai sesuatu yang sulit dan menyeramkan.

Salah satu pendekatan pembelajaran yang saat ini sedang digencarkan dalam pembelajaran matematika adalah Pendidikan Matematika Realistik. Pendidikan Matematika Realistik (PMR) adalah padanan Realistik Mathematics Education (RME), sebuah pendekatan pembelajaran matematika yang dikembangkan Freudenthal Institute di Belanda. PMR dikembangkan berdasar pandangan Freudenthal yang menyatakan matematika sebagai suatu aktivitas (Freudenthal, 1991; Gravemeijer, 1994). Lebih lanjut Gravemeijer (1994: 82) menjelaskan bahwa yang dapat digolongkan sebagai aktivitas tersebut meliputi aktivitas pemecahan masalah, mencari masalah dan mengorganisasi pokok persoalan.

Secara umum karakteristik pendekatan PMR adalah sebagai berikut: menggunakan masalah kontekstual, menggunakan model, menggunakan kontribusi siswa, adanya interaksi dalam proses pembelajaran, dan menggunakan berbagai teori belajar yang relevan, saling terkait, dan terintegrasi dengan topik pembelajaran lainnya (Gravemeijer, 1994). Penggunaan masalah kontekstual yang dikenal siswa dan juga penggunaan model dalam kehidupan seharihari siswa diharapkan dapat menumbuhkan rasa percaya diri dan membuat siswa merasa senang belajar matematika, sehingga pada saat menyelesaikan masalah kontekstual yang diberikan, siswa akan berani mengungkapkan pendapatnya. Interaksi yang terjadi antara siswa dengan guru dan antar siswa itu sendiri diharapkan dapat menumbuhkan rasa senang pada diri siswa. Kontribusi siswa 
dalam menyelesaikan masalah kontekstual dan dalam memahami keterkaitan antara masalah yang dihadapi dengan pengetahuan yang telah ia miliki diharapkan dapat meningkatkan keterampilan kognitif berpikir kritis siswa.

Menurut Usdiyana, dkk (2009) pembelajaran matematika realistik dapat meningkatkan kemampuan berpikir logis siswa. Sedangkan menurut Hasratuddin (2010) dalam disertasinya menunjukkan bahwa pembelajaran matematika dengan PMR dapat meningkatkan kemampuan berpikir kritis dan kecerdasan emosional siswa SMP kelas VIII. Penelitian lain yang dilakukan Somakim (2009) juga menunjukkan bahwa dengan menggunakan pendekatan PMR dapat meningkatkan kemampuan berpikir kritis matematik dan selfefficacy matematika siswa SMP. Jannah (2008) juga mengungkapkan penerapan penggunaan model dan kontribusi siswa pada pendekatan PMR dapat meningkatkan pemahaman konsep siswa.

Meskipun pendekatan PMR telah terbukti secara empiris dapat meningkatkan berbagai kemampuan siswa, tetapi guru masih kesulitan dalam menerapkan pendekatan PMR pada pembelajaran matematika. Hal ini dikarenakan belum adanya media yang sesuai dengan pendekatan PMR yang dapat digunakan langsung oleh guru. Dengan jumlah jam mengajar yang begitu padat dan berbagai kesibukan menata administrasi pembelajaran mereka, banyak guru yang kesulitan baik dari segi waktu maupun kemampuan dalam membuat media yang sesuai dengan pendekatan PMR. Untuk itu maka dikembangkan lembar kerja siswa berbasis pendekatan PMR yang diharapkan dapat membantu guru dalam melaksanakan pembelajaran matematika dengan menggunakan pendekatan PMR.

\section{METODE PENELITIAN}

Penelitian ini merupakan penelitian pengembangan atau research and development. Metode penelitian pengembangan adalah metode penelitian yang digunakan untuk menghasilkan produk tertentu dan menguji keefektifan produk tersebut (Sugiyono, 2010: 407). Model pengembangan yang digunakan dalam penelitian ini adalah model pengembangan prosedural, yaitu model yang bersifat deskriptif, menunjukkan langkah-langkah yang harus diikuti untuk 
menghasilkan produk (Depdiknas, 2008:7).

Prosedur penelitian pengembangan yang digunakan dalam penelitian ini mengacu kepada prosedur penelitian pengembangan menurut Borg dan Gall yang oleh Depdiknas (2008: 11) telah disederhanakan menjadi lima langkah utama sebagai berikut.

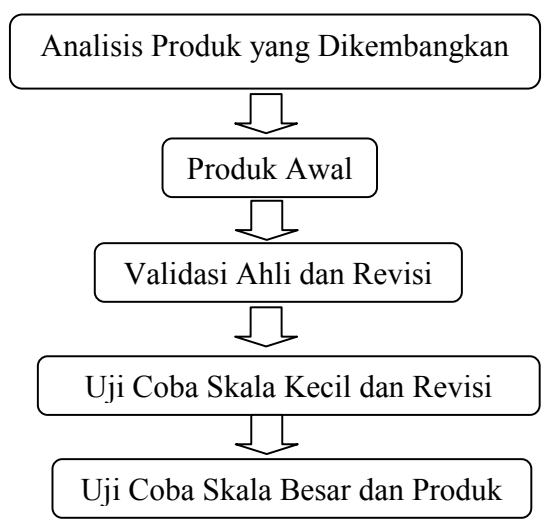

\section{HASIL DAN PEMBAHASAN}

Penelitian ini difokuskan pada proses pengembangan, kualitas, dan keefektifan lembar kerja siswa pada materi himpunan berbasis pendekatan PMR yang dikembangkan. Hasil dari proses pengembangan:

\section{A. Hasil Analisis Produk yang Dikembangkan}

Hasil analisis kebutuhan siswa SMP/MTs diperoleh dengan melakukan observasi dan wawancara tidak terstruktur dengan guru matematika SMP/MTs. Hasil observasi menunjukkan bahwa di sekolah belum tersedia lembar kerja siswa yang sesuai dengan pendekatan PMR. Meskipun pendekatan PMR menggunakan benda-benda di sekitar siswa ataupun benda-benda yang dapat dibayangkan siswa, tetapi bantuan lembar kerja siswa tetap dibutuhkan untuk membantu guru dalam menjelaskan materi. Lembar kerja siswa yang tersedia di sekolah hanya berisi ringkasan materi dan latihan soal yang berisi huruf dan angka saja. Hal ini tentu membuat siswa merasa bosan dan tidak tertarik untuk mempelajari materi matematika. Begitu pula dalam mempelajari materi himpunan untuk siswa SMP/MTs 
kelas VII di mana siswa masih diberikan contoh abstrak tentang himpunan. Padahal materi himpunan sebenarnya dapat dijelaskan melalui pendekatan PMR. Berdasarkan wawancara yang dilakukan kepada guru matematika diperoleh hasil bahwa guru sebenarnya ingin menggunakan berbagai macam pendekatan dalam pembelajaran matematika. Namun mereka masih terkendala dengan media yang akan mereka gunakan jika menggunakan pendekatan pembelajaran yang bermacam-macam tersebut. Meskipun banyak penelitian yang telah menunjukkan bahwa berbagai pendekatan pembelajaran matematika seperti PMR terbukti dapat meningkatkan kemampuan siswa, baik itu kemampuan berpikir maupun kemampuan lainnya. Kendala waktu karenan begitu banyak pekerjaan yang harus mereka lakukan menjadi salah satu faktor penyebab guru tidak bisa mempersiapkan media yang tepat. Berdasarkan hasil analisis kebutuhan tersebut, maka dilakukan pengembangan produk berupa lembar kerja siswa berbasis pendekatan PMR khususnya pada materi himpunan untuk siswa SMP/MTs. Meskipun demikian, karena keterbatasan penelitian, maka yang dikembangkan dalam produk ini hanya pada materi himpunan dengan ketentuan sebagai berikut:

SK : Menggunakan konsep himpunan dan diagram Venn dalam pemecahan masalah.

KD : (1) Menyajikan himpunan dengan diagram Venn dan (2) Menggunakan konsep himpunan dan diagram Venn dalam pemecahan masalah.

Indikator :

a. Menyajikan irisan dua himpunan dengan diagram Venn.

b. Menyajikan gabungan dua himpunan dengan diagram Venn.

c. Menyajikan selisih suatu himpunan dari himpunan lainnya dengan diagram Venn.

d. Menyajikan komplemen suatu himpunan dengan diagram Venn.

e. Menyelesaikan masalah dengan menggunakan diagram Venn dan konsep himpunan. 


\section{F. Hasil Pengembangan Produk Awal}

Hasil dari pengembangan produk awal meliputi:

a. Hasil pengumpulan materi pendukung pada pokok bahasan himpunan. Materi pendukung diperoleh dari berbagai sumber buku matematika kelas VII SMP/MTs dan dari internet yang meliputi: materi himpunan, cara menyajikan himpunan, dan cara menyelesaikan masalah dengan menggunakan konsep himpunan. Selain materi himpunan, pada tahap ini juga menghasilkan kumpulan gambar dan animasi yang sesuai dengan materi himpunan.

b. Hasil pembuatan desai awal LKS

Desai awal dibuat berdasarkan semua bahan yang telah dikumpulkan. Desain awal yang dibuat meliputi: desain cover yang berhubungan dengan materi himpunan, susunan dari materi yang akan dimuat dalam LKS, dan gambar/animasi yang bersesuain dengan materi yang akan dimuat, serta soal yang akan digunakan dalam LKS, penyesuaian materi dengan pendekatan PMR. Prinsip dan karakteristik pendekatan PMR yang dimuat dalam LKS meliputi: (1) Memberikan kesempatan kepada siswa untuk memahami masalah kontekstual, dan memberikan kesempatan bertanya tentang apa yang belum mereka pahami (use of context); (2) Memberikan kesempatan kepada siswa untuk menyelesaikan masalah kontekstual yang diberikan (interactivity, student contribution, dan use of models); (3) Memberikan kesempatan kepada siswa untuk membandingkan dan mendiskusikan jawaban LKS yang telah mereka kerjakan (interactivity dan student contribution); dan (4) Mengarahkan siswa untuk menyimpulkan (interactivity dan student contribution)

c. Hasil pembuatan LKS berbasis pendekatan PMR LKS berbasis pendekatan PMR untuk siswa SMP/MTs pada materi himpunan berdasarkan desain awal LKS kemudian disebut dengan draft I. draft I ini selanjutnya divalidasikan dan dinilai oleh validator ahli. 


\section{G. Hasil Validasi Ahli dan Revisi}

Draft I divalidasi dan dinilai oleh tiga orang validator ahli dengan ketentuan, yang bersangkutan telah memperoleh gelar Magister dan menguasai materi yang divalidasikan. Berikut adalah hasil validasi untuk aspek ketermuatan pendekatan PMR dalam LKS yang dikembangkan dari ketiga orang validator ahli.

\section{Tabel 1}

Hasil Penilaian Validator terhadap Kualitas Ketermuatan Pendekatan PMR dalam Draft I

\begin{tabular}{|llc|}
\hline & & Data Hasil Penelitian \\
\hline 1.) & Jumlah Kriteria & $=4$ \\
2.) & Skor Total & $=44$ \\
3.) & Rata-rata & $=14,67$ \\
4.) & Skor Tertinggi & $=1$ \\
5.) & Skor Terendah & $=4 \times 4=16$ \\
6.) & Skor Tertinggi Ideal & $=4 \times 1=4$ \\
7.) & Skor Terendah Ideal & $=\frac{1}{2}(16+4)=10$ \\
& $\bar{X}$ & $=\frac{1}{6}(16-4)=2$ \\
8.) & $X_{a}$ & $=4 \times 4 \times 3=48$ \\
& & $=91,67 \%$ \\
9.) & $M_{a}$ & \\
10.) & Skor Maksimal Ideal & \\
11.) & Persentase &
\end{tabular}

Hasil penilaian di atas kemudian diinterpretasikan berdasarkan tabel sebagai berikut. (Sudjana, 1989: 126-127) 
Tabel 2

Pedoman Konversi Skor Hasil Penelitian sesuai Tabel 1

\begin{tabular}{|c|c|c|}
\hline No. & Rentang Skor & Kategori \\
\hline 1. & $13<x_{a}$ & Sangat baik \\
\hline 2 & $11<x_{a} \leq 13$ & Baik \\
\hline 3 & $9<x_{a} \leq 11$ & Kurang baik \\
\hline 4 & $x_{a} \leq 9$ & $\begin{array}{c}\text { Sangat kurang } \\
\text { baik }\end{array}$ \\
\hline
\end{tabular}

Rata-rata $\left(x_{a}\right)$ kualitas draft I dilihat dari aspek ketermuatan pendekatan PMR berdasarkan penilaian tiga orang validator adalah sebesar 14,67 (91,67\%). Dengan kata lain, kualitas draft I dilihat dari aspek ketermuatan pendekatan PMR berada pada kategori sangat baik.

\section{Tabel 3}

Hasil Penilaian Validator terhadap Kualitas Keseluruhan Draft I

\begin{tabular}{|cc|}
\hline \multicolumn{2}{|c|}{ Data Hasil Penelitian } \\
\hline Jumlah Kriteria & $=19$ \\
Skor Total & $=70$ \\
Rata-rata & $=4$ \\
Skor Tertinggi & $=19 \times 4=76$ \\
Skor Terendah & $=19 \times 1=19$ \\
Skor Tertinggi Ideal & $=\frac{1}{2}(76+19)=47,5$ \\
Skor Terendah Ideal & \\
$\overline{X_{b}}$ & $=\frac{1}{6}(76-19)=9,5$ \\
& $=4 \times 19 \times 3=228$ \\
$M_{b}$ & $=90,35$ \\
& \\
Skor Maksimal Ideal & \\
Persentase &
\end{tabular}


Hasil penilaian di atas kemudian diinterpretasikan berdasarkan tabel sebagai berikut. (Sudjana, 1989: 126-127)

\section{Tabel 4}

Pedoman Konversi Skor Hasil Penelitian sesuai Tabel 3

\begin{tabular}{|c|c|}
\hline Rentang Skor & Kategori \\
\hline $61,75<x_{b}$ & Sangat baik \\
\hline $52,25<x_{b} \leq 61,75$ & Baik \\
\hline $42,75<x_{b} \leq 52,25$ & Kurang baik \\
\hline$x_{b} \leq 42,75$ & Sangat kurang baik \\
\hline
\end{tabular}

Rata-rata $\left(x_{b}\right)$ kualitas draft I secara keseluruhan berdasarkan penilaian tiga orang validator adalah sebesar 70 (90,35\%). Dengan kata lain, secara keseluruhan draft I memiliki kualitas sangat baik.

Hasil draft I yang telah divalidasi dan dinilai kemudian diperbaiki sesuai saran validator. Untuk selanjutnya draft I tersebut disebut sebagai draft II.

\section{H. Hasil Uji Coba Lapangan Skala Kecil dan Revisi Produk}

Uji coba lapangan skala kecil dilakukan dengan membagikan draft II pada enam sumber data. Setelah itu, sumber data diminta untuk memberikan komentar/saran terhadap draft II tersebut. Berikut adalah hasil uji coba lapangan skala kecil.

a. Seluruh sumber data menyatakan bahwa LKS sangat menarik dan tidak membosankan.

b. Tingkat kesukaran soal dalam LKS diharapkan dapat diturunkan. Saran ini akan menjadi pertimbangan dan dikonsultasikan kepada guru SMP/MTs.

Saran ataupun kritik dari keenam sumber data ditindaklanjuti sesuai keterangan di atas. Draft II yang sudah melalui tahap uji coba lapangan skala kecil selanjutnya disebut draft III. Draft III selanjutnya digunakan pada uji coba skala besar. 


\section{Hasil Uji Coba Lapangan Skala Besar dan Produk Akhir}

Uji coba skala besar dilaksanakan pada kelas VII salah satu MTs Swasta dengan jumlah siswa sebanyak 35 orang. Uji coba lapangan skala besar yang dilaksanakan menghasilkan data sebagai berikut.

\section{Tabel 5}

Hasil Uji Coba Lapangan Skala Besar

\begin{tabular}{|c|c|}
\hline \multicolumn{2}{|c|}{ Data Hasil Tes Siswa } \\
\hline $\begin{array}{c}\text { Jumlah siswa yang mengi- } \\
\text { kuti tes }\end{array}$ & $=35$ \\
\hline Nilai tertinggi & $=100$ \\
\hline Nilai terendah & $=54$ \\
\hline Rata-rata nilai & $=82,37$ \\
\hline Variansi & $=156,5933$ \\
\hline Jumlah siswa yang me- & $=29$ \\
\hline menuhi KKM & $=82,86 \%$ \\
\hline
\end{tabular}

Derdasarkan data di atas, terlihat bahwa persentase ketuntasan siswa setelah menggunakan LKS berbasis pendekatan PMR adalah 82,86\%. Hal ini berarti menurut Sudjana (1989: 118) LKS berbasis PMR yang dikembangkan sangat efektif digunakan di SMP/MTs.

Selain data hasil tes setelah mengalami pembelajaran dengan menggunakan LKS, pada tahap ini diperoleh juga data hasil wawancara untuk memperoleh respon siswa setelah meenggunakan LKS. Sumber data adalah sembilan orang siswa dengan ketentuan tiga orang siswa berkemampuan rendah, tiga orang siswa berkemampuan sedang, dan tiga orang berkemampuan tinggi. Dari sembilan orang siswa tersebut, semuanya memberikan respon positif terhadap penggunaan LKS berbasis pendekatan PMR. artinya siswa merasa senang belajar matematika materi himpunan dengan menggunakan LKS berbasis pendekatan PMR. Meskipun demikian ada satu siswa dari kelompok siswa 
berkemampuan rendah yang mengaku membutuhkan waktu yang agak lama untuk mempelajarinya. Namun, hal tersebut dapat ditindaklanjuti dengan memberikan bantuan berupa bimbingan pada saat pembelajaran berlangsung.

\section{KESIMPULAN DAN SARAN}

\section{Kesimpulan}

LKS Berbasis Pendekatan PMR pada Materi Himpunan untuk Siswa SMP/MTs hasil penelitian pengembangan ini terdiri atas empat bagian utama yaitu, LKS 1, LKS 2, LKS 3, dan LKS 4. Bagian tambahan dari LKS terdiri atas cover, Kata Pengantar, Daftar Isi, Daftar Pustaka, dan Profil Penulis. Kualitas dari LKS berbasis pendekatan PMR adalah sebagai berikut.

1. Dalam upaya pemuatan prinsip dan karakteristik pendekatan PMR, LKS memiliki kualitas yang sangat baik berdasarkan penilaian validator ahli dengan nilai 14,67 (91,67\%).

2. Secara keseluruhan LKS berbasis pendekatan PMR ini sudah valid dan memiliki kualitas sangat baik berdasarkan penilaian validator ahli dengan nilai $70(90,35 \%)$.

Selain kualitas di atas, diperoleh juga respon siswa terhadap penggunaan LKS berbasis pendekatan PMR dari sembilan yang berasal dari kelompok siswa berkemampuan rendah, sedang dan tinggi, semuanya memberikan respon yang positif. Selain itu, LKS yang dikembangkan juga sangat efektif digunakan di sekolah. Hal ini berdasarkan persentase ketuntasan siswa setelah melakukan pembelajaran dengan menggunakan LKS berbasis pendekatan PMR, yaitu 82,86\%. Artinya sebesar 82, 86\% dari seluruh siswa yang mengikuti ujian telah memperoleh nilai lebih dari atau sama dengan 75 .

\section{Saran}

1. Dapat dilakukan penelitian pengembangan untuk materi-materi yang lebih beragam lagi.

2. Penyusunan LKS harus memperhatikan karaktetistik dari peserta didik agar lebih mudah dicerna oleh siswa. 


\section{DAFTAR PUSTAKA}

Depdiknas. 2003. Pedoman Khusus Pembelajaran Tuntas (Mastery Learning). Jakarta: Depdiknas.

Freudenthal, H. 1973. Mathematics as an Educational Task. Dordrecht: Reidel.

Gravemeijer, K.P.E. 1994. Developing Realistic Mathematics Education. Utrecht: CD Press.

Hasratuddin . 2010. Meningkatkan Kemampuan Berpikir Kritis dan Kecerdasan Emosional Siswa SMP Melalui Pendekatan Matematika Realistik. Disertasi. Bandung: UPI..

Hudojo, H. 1998. Pembelajaran Matematika Menurut Pandangan Konstruktivistik. Makalah disajikan pada Seminar Nasional "Upaya-upaya Meningkatkan Peran Pendidikan Matematika dalam Era Globalisasi". Program Pasca Sarjana IKIP Malang. Malang: 4 April.

Ibrahim, dan Suparni. 2008. Strategi Pembelajaran Matematika. Yogyakarta: Bidang Akademik UIN Suka.

Jannah, Ukhti Raudhatul. 2008. Pembelajaran Kubus dan Balok Dengan Penerapan Penggunaan Model dan Kontribusi Siswa di Kelas VIII SMP Islam Al-Ma'arif 01 Singosari. Tesis. Malang: Universitas Negeri Malang.

Mahmudi, Ali. 2009. Mengembangkan Kemampuan Berpikir Siswa melalui Pembelajaran Matematika Realistik. Makalah disajikan pada Seminar Nasional Pendidikan, dan Penerapan MIPA. FMIPA UNY. Yogyakarta: 16 Mei. 
Puskur. 2002. Kurikulum dan Hasil Belajar. Kompetensi Dasar Mata Pelajaran Matematika Sekolah Dasar dan Madrasah Ibtidaiyah. Jakarta: Balitbang Depdiknas.

Ruseffendi, E.T.. 2001. Evaluasi Pembudayaan Berpikir Logis Serta Bersikap Kritis dan Kreatif melalui Pembelajaran Matematika Realistik. Makalah disampaikan pada Lokakarya di Yogyakarta. Yogyakarta: Tidak diterbitkan.

Siswono, Tatag Yuli Eko. 2010. Penelitian Pendidikan Matematika. Surabaya: Unesa Uversity Press.

Somakim. 2009. Peningkatan Kemampuan Berpikir Kritis Dan Selfefficacy Siswa Sekolah Menengah Pertama Dengan Penggunaan Pendekatan Matematika Realistik. Disertasi. Bandung: UPI.

Sudjana, Nana. 1989. Penilaian Hasil Proses Belajar Mengajar. Bandung: Remaja Rosdakarya.

Sugiyono. 2008. Metode Penelitian Kuantitatif, Kualitatif, dan $R \mathcal{E} D$. Bandung: Alfabeta.

Usdiyana, Dian dkk. 2009. Meningkatkan Kemampuan Berpikir Logis Siswa SMP Melalui Pembelajaran Matematika Realistik. Jurnal Pengajaran MIPA, Vol. ISSN: 1412-0917 13 No. 1 April 2009. Bandung: Universitas Pendidikan Indonesia.

Wintarti, Atik dkk. 2008. Contextual Teaching and Learning Matematika Sekolah Menengah Pertama Kelas VII Edisi 4. Jakarta: Pusat Perbukuan, Depdiknas. 